\title{
Jak se léčí statiny v České republice?
}

Výsledky průzkumu STEP

\author{
Jaromír Hradec', Jan Bultas², Aleš Kmínek³, Václav Hlaváč̌, Romana Tylová3, Pavla Kadlecová4 \\ 'III. interní klinika, 1. lékařská fakulta Univerzity Karlovy a Všeobecné fakultní nemocnice, Praha \\ ${ }^{2}$ Farmakologický ústav, 3. lékařská fakulta Univerzity Karlovy, Praha \\ ${ }^{3}$ AstraZeneca Czech Republic, s.r.o., Praha \\ ${ }^{4}$ ADDS, s.r.o., Brno, Česká republika
}

Hradec J, Bultas J, Kmínek A, et al. Jak se léči statiny v České republice? Výsledky průzkumu STEP. Cor Vasa 2011;53:527-534.

Cíl: Statiny jsou u nás jedny z nejvíce předepisovaných léčiv vůbec. V ČR se za ně ročně vydává přibližně 2 miliardy Kč. Objektivní informace o tom, komu, proč, jak, kým a s jakými výsledky jsou u nás tyto látky podávány, však chybějí. Získat chybějící informace bylo cílem projektu STEP (Statin Therapy REsults in the Real World Practice in the Czech Republic), který byl realizován v ČR v roce 2010.

Soubor a metodika: $V$ tomto neintervenčním retrospektivním průzkumu byla sesbírána a analyzována data od 3190 nemocných, kteří byli léčeni ambulantními specialisty statiny po dobu minimálně 12 měsíců. Primárním cílem bylo zjistit podíl nemocných, kteří při minimálně 12měsiční léčbě statinem dosáhnou cílovou hodnotu LDL cholesterolu (LDL-CH). Nemocní byli rozděleni podle absolutního kardiovaskulárního rizika do tři skupin s cílovými hodnotami LDL cholesterolu podle současných doporučených postupů - skupina 1: primární prevence $(\mathrm{n}=597)-\mathrm{LDL}-\mathrm{CH}<3,0 \mathrm{mmol} / \mathrm{l}$; skupina 2: sekundární prevence $(\mathrm{n}=1 \mathrm{901})-\mathrm{LDL}-\mathrm{CH}<2,5 \mathrm{mmol} / \mathrm{l}$; skupina 3: mimořádně vysoké kardiovaskulární $(\mathrm{KV})$ riziko $(\mathrm{n}=692)-\mathrm{LDL}-\mathrm{CH}<2,0 \mathrm{mmol} / \mathrm{l}$.

Výsledky: Průměrný věk nemocných byl 63 roků, $59 \%$ z nich byli muži. Průměrný BMI =29,3 $\pm 4,6 \mathrm{~kg} / \mathrm{m}^{2}$, systolický TK = $134 \pm 15 \mathrm{~mm} \mathrm{Hg}$ a diastolický TK $=80 \pm 9 \mathrm{~mm} \mathrm{Hg}$. Léčba statiny trvala v průměru 3,7 $\pm 2,9$ roků s mediánem 3 roky. Průměrná vstupní hodnota LDL cholesterolu 3,58 $\pm 1,24 \mathrm{mmol} / \mathrm{l}$ klesla při minimálně 12 měsíců trvající léčbě statiny o $0,98 \mathrm{mmol} / \mathrm{l}(-22 \%)$. Cílové hodnoty LDL cholesterolu odpovídající příslušnému KV riziku bylo dosaženo u $46 \%$ všech nemocných (u $64 \%$ ve skupině $1 ;$ u 50 \% ve skupině 2 ; u $20 \%$ ve skupině 3 ). Hodnoty LDL cholesterolu $<3,0$ mmol/I bylo bez ohledu na KV riziko dosaženo u 75 \% všech nemocných. Nejužívanějším statinem byl atorvastatin (54\%), následovaný simvastatinem (21 \%) a rosuvastatinem (19\%). Nejčastěji používaná denní dávka tří nejpředepisovanějších statinů byla paradoxně stejná - $20 \mathrm{mg}$.

Závěr: Průzkum STEP přinesI dosud chybějící informace o používání statinů v léčbě dyslipidemií v běžné praxi v ČR. Výsledky dokumentují, že cílových hodnot LDL cholesterolu je dosaženo jen u necelé poloviny všech nemocných, kteří jsou léčeni statiny. Se stoupající rizikovostí klesá podíl nemocných, kteři dosáhnou cílovou hodnotu. U osob s velmi vysokým kardiovaskulárním rizikem je cílové hodnoty LDL cholesterolu dosaženo jen u pětiny léčených.

Klíčová slova: LDL cholesterol - Léčba dyslipidemií - Průzkum STEP - Statiny

Hradec J, Bultas J, Kmínek A, et al. How are statins used in the Czech Republic? STEP survey - results. Cor Vasa 2011;53:527-534.

Objective: Statins are one of the most prescribed medications in our country. About 2 billions CZK are being paid for them annually in the Czech Republic (CR). Objective information about to whom, why, how, by whom and with what results these medications are given is, however, missing. It was the aim of the STEP project (Statin Therapy REsults in the Real World Practice in the Czech Republic), which was carried out in the CR in 2010, to obtain the missing information.

Patients and methods: In this non-intervention retrospective survey, data from 3190 patients treated by statins for at least 12 months in specialized outpatient clinics were collected and analyzed. The primary aim was to establish the percentage of patients who attain the LDL cholesterol (LDL-C) goal during the treatment with statin lasting for at least 12 months. The patients were divided into 3 groups according to their absolute cardiovascular (CV) risk and the LDL-C goal was defined for each of these groups based on the current recommendations - group 1: primary prevention $(n=597)-L D L-C<3.0 \mathrm{mmol} / \mathrm{l}$; group 2: secondary prevention $(\mathrm{n}=1901)-\mathrm{LDL}-\mathrm{C}<2.5 \mathrm{mmol} / \mathrm{l}$; group 3: very high CV risk $(\mathrm{n}=692)-\mathrm{LDL}-\mathrm{C}<2.0 \mathrm{mmol} / \mathrm{l}$.

Results: The mean patients' age was 63 years, $59 \%$ of the patients were males. Mean BMl $=29.3 \pm 4.6 \mathrm{~kg} / \mathrm{m}^{2}$, systolic BP $=134 \pm 15 \mathrm{mmHg}$ and diastolic $\mathrm{BP}=80 \pm 9 \mathrm{mmHg}$. The mean duration of the treatment with statins was $3.7 \pm 2.9$ years with a median of 3 years. The mean baseline LDL cholesterol concentration of $3.58 \pm 1.24 \mathrm{mmol} / \mathrm{l}$ decreased during the treatment with statins lasting for at least $12 \mathrm{months}$ by $0.98 \mathrm{mmol} / \mathrm{l}(-22 \%)$. The LDL cholesterol goal corresponding to the given CV risk was attained in $46 \%$ of all patients (by $64 \%$ in group 1 ; by $50 \%$ in group 2 ; by $20 \%$ in group 3). LDL cholesterol concentration $<3.0 \mathrm{mmol} / \mathrm{l}$ was attained in $75 \%$ of all patients irrespective of their CV risk. Atorvastatin (54\%) was the most often prescribed statin, followed by simvastatin (21\%) and rosuvastatin (19\%). Paradoxically, the most often prescribed dose was the same in these three most prescribed statins, i.e. $20 \mathrm{mg}$.

Conclusion: In STEP survey, the missing information concerning the use of statins for dyslipidemia treatment in daily clinical practice in the CR was obtained. The results show that LDL cholesterol goals are attained in less than half of the patients treated with statins. 
The higher the CV risk, the lower the percentage of patients attaining the goal. The LDL cholesterol goal is attained in only one of five treated patients with very high cardiovascular risk.

Key words: LDL cholesterol - Treatment of dyslipidemia - STEP survey - Statins

Adresa: Prof. MUDr. Jaromír Hradec, CSc., FESC; III. interní klinika 1. LF UK a VFN, U Nemocnice 1, 12808 Praha 2, e-mail: jhradec@vfn.cz

úvod

V České republice, podobně jako ve všech rozvinutých zemích, jsou kardiovaskulární onemocnění (KVO) nejčastější prríčinou mortality a závažné morbidity. I když se v posledních dvou desetiletích situace významně zlepšila, stále zůstávají KVO nejčastější příčinou úmrtí obyvatel ČR a umírá na ně přibližně dvakrát tolik nemocných než na zhoubné nádory. $\mathrm{V}$ roce 2009 na ně zemřelo 54100 lidí, což představovalo $50,4 \%$ všech úmrtí. Přitom samotná ischemická choroba srdeční (ICHS) je př́činou přibližně $40 \%$ všech úmrtí. ${ }^{1}$ V posledních 20 letech pozorujeme v ČR významný pokles standardizované kardiovaskulární mortality, nejvýraznější je pokles mortality na cerebrovaskulární a koronární príhody, který dosáhl $50 \%$ pro obě pohlaví. ${ }^{2}$ Jeho př́činy nejsou zcela jasné. Nové a účinnější způsoby léčby jsou odpovědné pouze za část tohoto poklesu. Daleko větší význam zřejmě mají preventivní opatření, jako jsou změny životního stylu, např. pokles kouření cigaret $\mathrm{v}$ některých skupinách obyvatelstva, zdravější stravovací návyky, ale také neustále se zlepšující detekce a účinnější léčba hypertenze i dyslipidemií a obecně důslednější uplatňování zásad primární a sekundární prevence. ${ }^{3,4}$ Kardiovaskulární onemocnění jsou u nás také nejčastější príičinou hospitalizací nemocných ve věku nad 60 let na interních odděleních nemocnic.

Dyslipidemie je jedním z hlavních ovlivnitelných rizikových faktorů onemocnění aterosklerotického původu - ischemické choroby srdeční (ICHS), cerebrovaskulární ischemické choroby a ischemické choroby dolních končetin. Dominující úlohu hraje zejména při vzniku a rozvoji ICHS. Léčba dyslipidemií je proto jedním ze základních preventivních opatření u aterosklerotických $\mathrm{KVO}$, především ICHS. Jejím základem jsou opatření nefarmakologická, především úprava stravovacích návyků - dieta s nízkým obsahem cholesterolu. Jak však ukazují intervenční studie, dietní léčba má svá omezení, pokles LDL cholesterolu nepřesahuje v prvém roce $15 \%$, v řadě studií byl dokonce $<10 \%$. S postupem doby, jak ubývá adherence $\mathrm{k}$ dietě, jsou výsledky ještě skromnější. U většiny nemocných tak tato nefarmakologická opatření nestačí a je nutno zahájit farmakoterapii hypolipidemickými léky. Z hypolipidemik pak mají naprosto dominantní postavení statiny (inhibitory 3-hydroxy-3-methyl-glutaryl-koenzym A reduktázy - HMG-CoA reduktázy). Mají za sebou naprosto přesvědčivé důkazy $\mathrm{v}$ podobě výsledků desítek velkých klinických studií o tom, že významně snižují kardiovaskulární morbiditu i mortalitu. Metaanalýza velkých randomizovaných statinových klinických studií ukázala, že snížení LDL cholesterolu statinem o $1 \mathrm{mmol} / \mathrm{l}$ má u osob s vysokým kardiovaskulárním rizikem za následek významné snížení koronárních příhod o $25 \%$, snížení koronární mortality o $19 \%$ a dokonce i snížení celkové mortality o $12 \% .{ }^{5}$ Tento př́źznivý účinek léčby statiny je prokazatelný v celém spektru hodnot cholesterolemie, resp. plazmatické koncentrace LDL cholesterolu, ale je tím větší, čím vyšší je výchozí absolutní kardiovaskulární riziko osob, jimž je statin podáván. Stále více důkazů také ukazuje na to, že čím nižší plazmatické koncentrace LDL cholesterolu se léčbou dosáhne, tím je prognóza lepší - platí tedy „čím níže, tím lépe“. 6 Dále je v klinických studiích doloženo, že léčba dyslipidemie má začít co nejdříve, platí tak též „čím dříve, tím lépe" a dokonce, jak bylo pozorováno ze sledování účinnosti v průběhu léčby, platí i poslední pravidlo „čím déle, tím, lépe“. To vše se odráží v doporučených postupech prevence KVO. Tak, jak nové randomizované klinické studie přinášejí nové důkazy, snižují se postupně plazmatické koncentrace LDL cholesterolu, které chceme hypolipidemickou léčbou dosáhnout, tzv. cílové hodnoty. Tyto cílové hodnoty se tak liší podle absolutního kardiovaskulárního rizika; čím je toto riziko vyšší, tím jsou cílové hodnoty nižšíi. ${ }^{3,4}$ Nejnovější doporučení České společnosti pro aterosklerózu pro diagnostiku a léčbu dyslipidemií $\mathrm{v}$ dospělosti uvádějí následující cílové hodnoty hypolipidemické léčby:?

> v obecné populaci a v primární prevenci u osob s nízkým absolutním kardiovaskulárním rizikem $(<5 \%$ podle SCORE) pro celkový cholesterol $<5 \mathrm{mmol} / \mathrm{l}$ a LDL cholesterol $<3 \mathrm{mmol} / \mathrm{l}$;

> pro nemocné v primární prevenci s vysokým kardiovaskulárním rizikem ( $\geq 5 \%$ podle SCORE), pro diabetiky a nemocné s již klinicky manifestním onemocněním aterosklerotického původu (sekundární prevence) pro celkový cholesterol $<4,5 \mathrm{mmol} / \mathrm{l}$ a LDL cholesterol $<2,5 \mathrm{mmol} / \mathrm{l}$;

> pro nemocné s mimořádně vysokým kardiovaskulárním rizikem (např. diabetik po prodělaném IM) jsou cílové hodnoty ještě nižší: pro celkový cholesterol $<4 \mathrm{mmol} / \mathrm{l}$ a pro LDL cholesterol $<2 \mathrm{mmol} / \mathrm{l}$, ovšem $\mathrm{s}$ vědomím, že se jich u řady nemocných nepodaří dosáhnout.

Statiny jsou u nás jedny $\mathrm{z}$ nejpředepisovanějších léčiv vůbec, vydává se za ně ročně přibližně 2 miliardy Kč. Objektivní informace o tom, komu, proč, jak, kým a s jakými výsledky jsou u nás tyto léky podávány, však chybějí. Získat chybějící informace bylo cílem projektu STEP.

\section{Soubor nemocných a metodika}

Protokol

Projekt STEP (Statin Therapy REsults in the Real World Practice in the Czech Republic) je neintervenční retrospektivní průzkum léčby statiny v ČR, ve kterém byla data sbírána v průběhu roku 2010. Přináší tedy informace o léčbě statiny v ČR v letech 2009-2010. Primárním cílem tohoto projektu bylo zjistit podíl nemocných, kteří dosáhnou při léčbě statiny 
trvající minimálně jeden rok cílových hodnot LDL cholesterolu doporučovaných současnými doporučenými postupy podle jednotlivých rizikových kategorií. Sekundárními cíli pak bylo: 1) zjistit absolutní a relativní změnu v hodnotách celkového, LDL a HDL cholesterolu a triglyceridů při roční léčbě statiny; 2) stanovit podíl nemocných, kteří dosáhnou cílových hodnot dalších lipidových parametrů, konkrétně celkového a HDL cholesterolu a triglyceridů; 3) u nemocných s dyslipidemií popsat léčbu statiny a pokusit se najít vztah mezi zvolenou léčbou (přípravek a denní dávka), kardiovaskulárním rizikem a plazmatickou koncentrací LDL cholesterolu po jednom roce léčby.

Uspořádání průzkumu bylo jednoduché a je schematicky shrnuto na obrázku 1. Podle protokolu bylo plánováno zařadit $\mathrm{v}$ celkem 340 centrech rovnoměrně rozmístěných po celé ČR přibližně 3400 nemocných s dyslipidemií, kteří jsou minimálně po dobu jednoho roku léčeni jakýmkoli statinem, a přitom mají v dokumentaci výsledky minimálně dvou vyšetření lipidogramu nebo alespoň LDL cholesterolu v odstupu jednoho roku. První laboratorní výsledek musel být získán při zahájení léčby statinem nebo při převzetí nemocného do péče specialisty a druhý, resp. poslední s odstupem nejméně 12 měsíců, přičemž ale nesměl být starší než šest měsíců ode dne sběru dat. Průzkumu se nakonec zúčastnilo 268 ambulantních lékařů - specialistů, na které se nevztahují žádná preskripční omezení pro statiny. Ze zúčastěných lékařu bylo $40 \%$ kardiologů, $30 \%$ internistů, 19 \% diabetologů a 11 \% lékařů specializovaných lipidových poraden, kteří u nemocných splňujících vstupní kritéria zaznamenávali anonymizované údaje do předtištěného formuláře pro záznam dat.

\section{Soubor nemocných}

Do průzkumu bylo celkem zařazeno 3248 nemocných, data 58 nemocných $(1,8 \%)$ byla vyřazena $\mathrm{z}$ analýzy pro porušení protokolu, nejčastěji proto, že nebyla zaznamenána druhá hodnota lipidogramu (LDL cholesterolu), nebo nebyl dodržen interval mezi oběma hodnotami, nebo druhá hodnota byla starší než šest měsíců. Analyzována byla data od 3190 nemocných (obrázek 2). Tito nemocní byli podle kardiovaskulárního rizika rozděleni do tří podskupin:

> podskupina $1(\mathrm{n}=579 ; 19 \%)$ : obecná populace nemocných v primární prevenci s cílovými hodnotami při léčbě statiny pro celkový cholesterol $<5 \mathrm{mmol} / \mathrm{l}$ a LDL cholesterol < $3 \mathrm{mmol} / \mathrm{l}$;

> podskupina $2(\mathrm{n}=1901 ; 59 \%)$ : Nemocní v sekundární prevenci, kteří již mají klinicky manifestní aterosklerotické onemocnění (jsou napřr. po IM nebo po CMP)

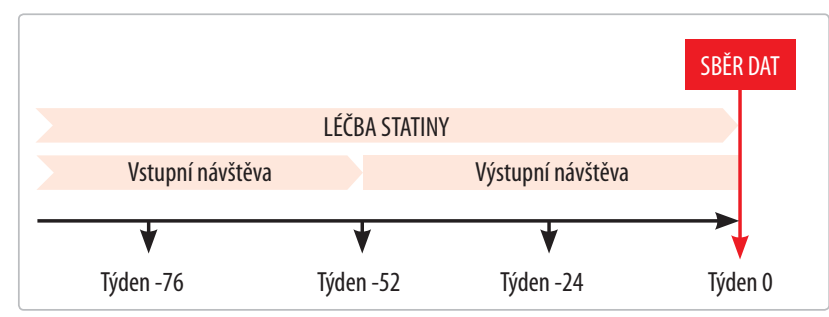

Obrázek 1 Schéma uspořádání průzkumu STEP a nemocní s DM s cílovými hodnotami při léčbě statiny pro celkový cholesterol $<4,5 \mathrm{mmol} / \mathrm{l}$ a LDL cholesterol $<2,5 \mathrm{mmol} / \mathrm{l}$;

> podskupina $3(\mathrm{n}=692 ; 22 \%)$ : nemocní s mimořádně vysokým kardiovaskulárním rizikem (např. nemocní po IM, kteří mají navíc současně diabetes mellitus) s cílovými hodnotami při léčbě statiny pro celkový cholesterol $<4,0 \mathrm{mmol} / \mathrm{l}$ a LDL cholesterol $<2,0 \mathrm{mmol} / \mathrm{l}$.

\section{Statistické hodnocení}

Propisovací kopie všech formulářo pro záznam dat byly zpracovány profesionální statistickou firmou ADDS s.r.o., Brno. Analýza dat byla provedena s pomocí software SAS, verze 9.1 nebo vyšší. Jednotlivé proměnné jsou popsány deskriptivními statistikami, doplněnými odhady přesnosti výpočtu (intervaly spolehlivosti). Výpočty intervalů spolehlivost a testy hypotéz byly provedeny na hladině významnosti $\mathrm{p}=0,05$. Počítány byly oboustranné intervaly spolehlivosti. Pro ověření normálního rozdělení spojitých parametrů byl použit Kolmogorovův-Smirnovův test, který je pro data o velkém rozsahu vhodnější než Shapirův-Wilkův test normality. Při normálním rozložení dat byly použity parametrické metody analýzy (t-test pro testování hypotéz a $95 \%$ intervaly spolehlivosti průměru), při výrazném porušení normálního rozložení dat byly pro analýzu použity neparametrické metody (pro popis parametrů interval spolehlivosti mediánu dle metody Hahna a Meekera ${ }^{8}$ a pro testování hypotéz Wilcoxonův znaménkový test). Pro testování hypotéz binárních či kategoriálních dat byl použit $\chi^{2}$ test.

Při výpočtech popisných statistik byly jednotlivé parametry analyzovány s ohledem na jejich charakter:

> spojité parametry byly popsány aritmetickým průměrem, směrodatnou odchylkou (SD), minimem, maximem, mediánem, horním a dolním kvartilem a 95\% intervalem spolehlivosti;

> kategoriální a binární parametry byly popsány absolutní a relativní četností (frekvenční tabulkou).

Tato neintervenční studie (průzkum) byla prováděna v souladu s etickými principy, které odpovídají Helsinské deklaraci (revize z roku 2000), v souladu se zákonem č. 378/2007 Sb., předpisy SÚKL a dle etického kodexu Asociace inovativního farmaceutického průmyslu. Podle protokolu nebyli nemocní $\mathrm{v}$ tomto průzkumu vystaveni žádným dodatečným diagnostickým procedurám ani nedostávali žádné léky navíc. Data byla získána ze zdravotnické dokumentace a byla před

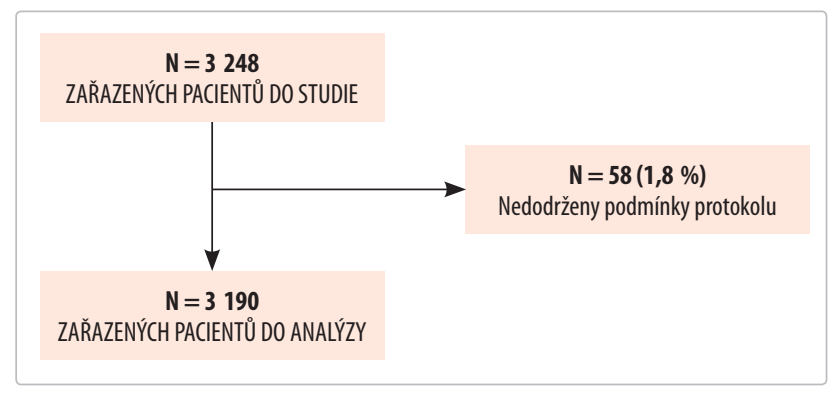

Obrázek 2 Přehled nemocných zařazených do studie 
analýzou anonymizovaná. Nebyl proto vyžadován ani souhlas etické komise ani informovaný souhlas nemocných. Pro analýzu dat byly použity epidemiologické metody. Průzkum byl sponzorován výzkumným grantem farmaceutické firmy AstraZeneca Czech Republic, s.r.o.

\section{Výsledky}

\section{Demografické údaje a klinická charakteristika}

Demografické údaje a některé klinické charakteristiky celého analyzovaného souboru a nemocných v jednotlivých podskupinách podle kardiovaskulárního rizika jsou shrnuty v tabulce 1 . Průměrný věk celého souboru byl $63 \pm 10,5$ roků, mužů bylo $59 \%$, nemocní měli průměrnou tělesnou hmotnost $85,9 \pm 15,6 \mathrm{~kg}$ a průměrný BMI 29,3 $\pm 4,6 \mathrm{~kg} / \mathrm{m}^{2}$. Jejich průměrný krevní tlak byl 133,7 $\pm 14,9 / 79,9 \pm 8,8 \mathrm{~mm} \mathrm{Hg}$. Aktivních kuřáků bylo v celém souboru $12 \%$, bývalých kuŕáků $28 \%$. Průměrná délka léčby statiny byla $3,7 \pm 2,9$ roku s mediánem 3 roky.

Mezi jednotlivými podskupinami podle kardiovaskulárního rizika byly významné rozdíly v počtu mužů a žen, ve věku, tělesné hmotnosti, BMI, systolickém krevním tlaku a počtu kuřáků. V diastolickém tlaku a délce léčby statiny rozdíl mezi podskupinami nebyl statisticky významný. Vzhledem $\mathrm{k}$ velkému počtu pacientů byly jako statisticky významné prokázány i malé (a z klinického pohledu nevýznamné) rozdíly mezi podskupinami. $\mathrm{V}$ délce léčby nebyl prokázán významný rozdíl, výsledky analýzy (především podíl nemocných s dosaženými cílovými hodnotami lipidových parametrů) tedy nemohou být ovlivněny délkou léčby.

\section{Primární ukazatel - dosažení cílové hodnoty LDL} cholesterolu

V celém analyzovaném souboru dosáhlo cílové hodnoty LDL cholesterolu odpovídající prríslušnému kardiovaskulárnímu riziku 46,2 \% nemocných. V podskupině 1 (nemocní se středním kardiovaskulárním rizikem $\mathrm{v}$ primární prevenci) dosáhlo cílovou hodnotu LDL cholesterolu $<3 \mathrm{mmol} / \mathrm{l}$
64,3 \% nemocných, v podskupině 2 (nemocní v primární prevenci s vysokým kardiovaskulárním rizikem, diabetici a nemocní v sekundární prevenci) dosáhlo cílovou hodnotu LDL cholesterolu $\leq 2,5 \mathrm{mmol} / 1$ 50,2 \% nemocných $\mathrm{a} \mathrm{v}$ podskupině 3 (nemocní s mimořádně vysokým kardiovaskulárním rizikem) dosáhlo cílovou hodnotu LDL cholesterolu $<2 \mathrm{mmol} / \mathrm{l}$ pouze $19,5 \%$ nemocných. Rozdíly $\mathrm{v}$ procentech nemocných, kteří dosáhli cílové hodnoty LDL cholesterolu, byly mezi jednotlivými podskupinami vysoce statisticky významné ( $<$ 0,001) (obrázek 3).

V celém analyzovaném souboru bez ohledu na kardiovaskulární riziko bylo léčbou statinem dosaženo plazmatické koncentrace LDL cholesterolu $<3$ mmol/1 u 75,1 \% nemocných. Tuto nejvolnější cílovou hodnotu dosáhlo nejméně nemocných $\mathrm{v}$ podskupině $1 \mathrm{~s}$ nejnižším KV rizikem (64,3 \%; $\mathrm{p}<0,001$ proti oběma zbývajícím podskupinám) a nejvíce nemocných $\mathrm{v}$ podskupině $2(79,5 \% ; \mathrm{p}<0,001$ proti oběma zbývajícím podskupinám). Přísnější cílovou hodnotu LDL cholesterolu $<2,5 \mathrm{mmol} / 1$ dosáhlo 46,1 \% všech nemocných, rozdíly mezi jednotlivými podskupinami byly podobné jako $\mathrm{v}$ předchozím případě. Nejpřísnější cílovou hodnotu LDL cholesterolu $<2$ mmol/l dosáhlo jen 19,1 \% všech nemocných. Tuto cílovou hodnotu dosáhlo opět nejvíce nemocných v podskupině 2 a nejméně v podskupině 1 (obrázek 4).

\section{Sekundární sledované ukazatele \\ 1. Absolutní a relativní změny hodnot jednotlivých lipidových parametrư při léčbě statiny}

Vstupní hodnoty jednotlivých lipidových parametrů, jejich absolutní změny $\mathrm{v}$ mmol/l i relativní změny $\mathrm{v}$ procentech $\mathrm{v}$ průběhu jednoroční léčby statiny $\mathrm{v}$ celém sledovaném souboru i v jednotlivých podskupinách podle kardiovaskulárního rizika jsou souhrnně uvedeny v tabulce 2 .

Průměrná vstupní plazmatická koncentrace LDL cholesterolu v celém souboru byla 3,58 \pm 1,24 mmol/l a po minimálně roční léčbě statiny klesla $\mathrm{v}$ průměru o $0,98 \pm 1,13 \mathrm{mmol} / \mathrm{l}(\mathrm{p}<0,001)$, což představuje pokles o $22 \%$ ( $<<0,001)$. Průměrná vstupní koncentrace celko-

Tabulka 1 Demografické údaje a některé klinické charakteristiky celého souboru nemocných a tří jeho podskupin podle kardiovaskulárního rizika

\begin{tabular}{|c|c|c|c|c|c|}
\hline Parametr (jednotky) & Celý soubor ( $n=3190)$ & Podskupina 1 ( $n=597)$ & Podskupina 2 ( $n=1901)$ & Podskupina $3(n=692)$ & $p^{*}$ \\
\hline Věk (roky) & $63 \pm 10,5$ & $60 \pm 10,8$ & $64 \pm 9,9$ & $61 \pm 11,1$ & $<0,001$ \\
\hline Pohlaví (\% mužů) & 59 & 51 & 64 & 55 & $<0,001$ \\
\hline Hmotnost (kg) & $85,9 \pm 15,6$ & $83,2 \pm 15,6$ & $87,0 \pm 15,5$ & $85,3 \pm 15,5$ & $<0,001$ \\
\hline $\mathrm{BMI}\left(\mathrm{kg} / \mathrm{m}^{2}\right)$ & $29,3 \pm 4,6$ & $28,3 \pm 4,4$ & $29,6 \pm 4,6$ & $29,2 \pm 4,6$ & $<0,001$ \\
\hline \multicolumn{6}{|l|}{ Krevní tlak } \\
\hline . systolický (mm Hg) & $133,7 \pm 14,9$ & $131,9 \pm 14,3$ & $134,1 \pm 14,9$ & $134,1 \pm 15,1$ & 0,015 \\
\hline - diastolický (mm Hg) & $79,9 \pm 8,8$ & $80,1 \pm 9,0$ & $79,9 \pm 8,8$ & $79,8 \pm 8,8$ & n.s. \\
\hline \multicolumn{6}{|l|}{ Kouření } \\
\hline - aktivní kuřák (\%) & 12 & 12 & 12 & 13 & $<0,001$ \\
\hline - exkuřák (\%) & 28 & 16 & 31 & 27 & \\
\hline Délka léčby statiny (roky) & $3,7 \pm 2,9$ & $3,6 \pm 3,0$ & $3,6 \pm 2,9$ & $3,9 \pm 3,1$ & n.s. \\
\hline
\end{tabular}




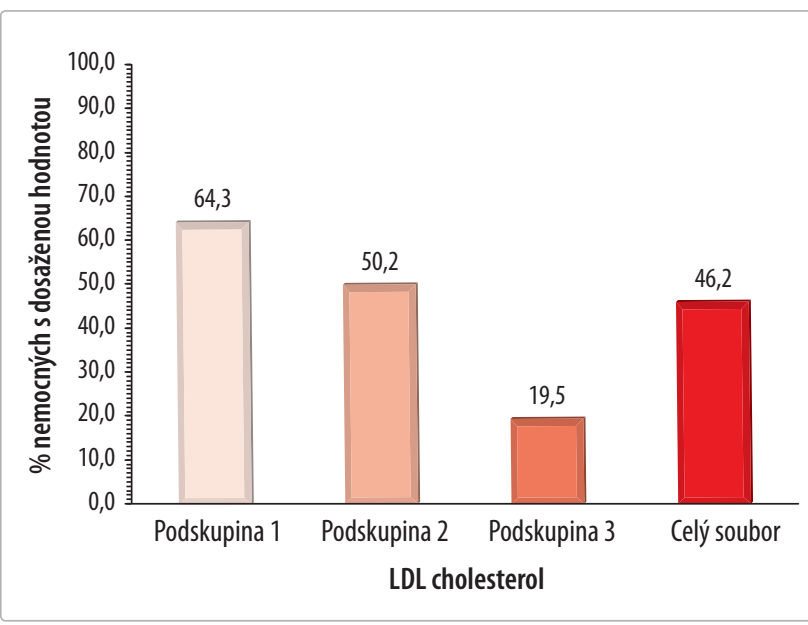

Obrázek 3 Primární sledovaný ukazatel v průzkumu STEP: podíl nemocných $(v \%)$ v celém souboru a v jednotlivých podskupinách podle kardiovaskulárního rizika, kteří dosáhli při minimálně roční léčbě statinem cílovou hodnotu LDL cholesterolu (cílové hodnoty: v podskupině $1<3,0 \mathrm{mmol} /$; $v$ podskupině $2<2,5 \mathrm{mmol} / /$; v podskupině $3<2,0 \mathrm{mmol} / \mathrm{l}$ )

vého cholesterolu v celém souboru byla $5,85 \pm 1,48 \mathrm{mmol} / \mathrm{l}$ a po roční léčbě statiny klesla $v$ průměru o $1,22 \pm 1,33 \mathrm{mmol} / \mathrm{l}$ $(\mathrm{p}<0,001)$, což představuje pokles o $18 \%(\mathrm{p}<0,001)$. Průměrná vstupní koncentrace HDL cholesterolu v celém souboru byla $1,32 \pm 0,42 \mathrm{mmol} / \mathrm{l}$ a po roční léčbě statiny stoupla $\mathrm{v}$ průměru o $0,02 \pm 0,32 \mathrm{mmol} / \mathrm{l}(\mathrm{p}<0,001)$, což představuje vzestup o $5 \%(\mathrm{p}<0,001)$. A konečně, průměrná vstupní koncentrace triglyceridů byla 2,16 $\pm 1,38 \mathrm{mmol} / \mathrm{l}$ a po roční léčbě statiny poklesla o $0,46 \pm 1,15 \mathrm{mmol} / \mathrm{l}$ $(\mathrm{p}<0,001)$, což představuje pokles o $10 \%(\mathrm{p}<0,001)$. Mezi jednotlivými podskupinami nemocných podle KV rizika nebyly v absolutním ani relativním poklesu jednotlivých lipidových parametrů nalezeny statisticky významné rozdíly. Jedinou výjimkou je HDL cholesterol, jehož absolutní změna byla během roční léčby v podskupinách 1 a 3 statisticky

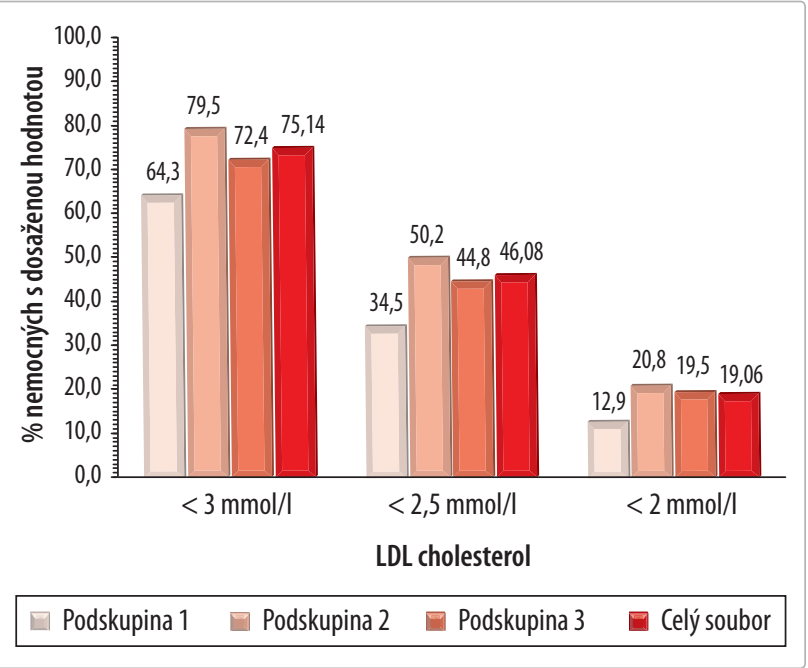

Obrázek 4 Podíl nemocných ( $\mathrm{v}$ \%) s dosaženými cílovými hodnotami LDL cholesterolu $<3 \mathrm{mmol} / \mathrm{l} ;<2,5 \mathrm{mmol} / \mathrm{l}$ $\mathrm{a}<2 \mathrm{mmol} / \mathrm{l} v$ celém souboru a $\mathrm{v}$ jednotlivých podskupinách

nevýznamná, i když relativní změna dosáhla statistické významnosti.

\section{Podíl nemocných, kteří dosáhli cílových hodnot ostatních lipidových parametrů}

V celém analyzovaném souboru dosáhlo cílové hodnoty celkového cholesterolu odpovídající prríslušnému kardiovaskulárnímu riziku 45,2 \% nemocných. V podskupině 1 (nemocní s nízkým kardiovaskulárním rizikem v primární prevenci) dosáhlo cílovou hodnotu celkového cholesterolu $<5 \mathrm{mmol} / \mathrm{l}$ $55,1 \%$ nemocných, v podskupině 2 (nemocní v primární prevenci s vysokým kardiovaskulárním rizikem, diabetici a nemocní v sekundární prevenci) dosáhlo cílovou hodnotu celkového cholesterolu $\leq 4,5 \mathrm{mmol} / 1$ 50,7 \% nemocných a vodskupině 3 (nemocní s mimořádně vysokým kardiovaskulárním rizikem) dosáhlo cílovou hodnotu celkového

Tabulka 2 Vstupní hodnoty, absolutní ( $\mathrm{vmmol} / \mathrm{l})$ a relativní ( $\mathrm{v}$ \%) změny jednotlivých lipidových parametrů v celém souboru a jednotlivých podskupinách podle kardiovaskulárního rizika

\begin{tabular}{|c|c|c|c|c|}
\hline Lipidový parametr & Celý soubor ( $n=3190$ ) & Podskupina $1(n=597)$ & Podskupina 2 ( $n=1901)$ & Podskupina $3(n=92)$ \\
\hline $\begin{array}{l}\text { LDL cholesterol: } \\
\text { - vstupní (mmol/l) } \\
\text { - abs. změna (mmol/l) } \\
\text { - rel. změna }(\%)\end{array}$ & $\begin{array}{c}3,58 \pm 1,24 \\
-0,98 \pm 1,13^{*} \\
-21^{*}\end{array}$ & $\begin{array}{c}3,86 \pm 1,19 \\
-1,09 \pm 1,19^{*} \\
-23^{*}\end{array}$ & $\begin{array}{c}3,37 \pm 10,7 \\
-0,85 \pm 1,02^{*} \\
-20^{*}\end{array}$ & $\begin{array}{c}3,91 \pm 1,55 \\
-1,24 \pm 1,30^{*} \\
-25^{*}\end{array}$ \\
\hline $\begin{array}{l}\text { Celkový cholesterol: } \\
\text { - vstupní (mmol/l) } \\
\text { - abs. změna (mmol/l) } \\
\text { - rel. změna }(\%)\end{array}$ & $\begin{array}{c}5,85 \pm 1,48 \\
-1,22 \pm 1,33^{*} \\
-18^{*}\end{array}$ & $\begin{array}{c}6,23 \pm 1,40 \\
-1,31 \pm 1,36^{*} \\
-018^{*}\end{array}$ & $\begin{array}{c}5,59 \pm 1,33 \\
-1,08 \pm 1,23 \\
-16\end{array}$ & $\begin{array}{c}6,23 \pm 1,77 \\
-1,53 \pm 1,50^{*} \\
-21^{*}\end{array}$ \\
\hline $\begin{array}{l}\text { HDL cholesterol: } \\
\text { - vstupní (mmol/l) } \\
\text { - abs. změna (mmol/l) } \\
\text { - rel. změna }(\%)\end{array}$ & $\begin{array}{c}1,32 \pm 0,42 \\
0,02 \pm 0,32^{*} \\
+5^{*}\end{array}$ & $\begin{array}{c}1,41 \pm 0,41 \\
0,02 \pm 0,30 \\
+4^{+}\end{array}$ & $\begin{array}{c}1,28 \pm 0,38 \\
0,03 \pm 0,28^{*} \\
+5,4^{*}\end{array}$ & $\begin{array}{c}1,35 \pm 0,51 \\
0,00 \pm 0,41 \\
+4,3^{+}\end{array}$ \\
\hline $\begin{array}{l}\text { Triglyceridy: } \\
\text { - vstupní (mmol/l) } \\
\text { - } \text { abs. změna (mmol/l) } \\
\text { - rel. změna }(\%)\end{array}$ & $\begin{array}{c}2,16 \pm 1,38 \\
-0,46 \pm 1,15^{*} \\
-10^{*}\end{array}$ & $\begin{array}{c}2,10 \pm 1,39 \\
-0,43 \pm 1,21^{*} \\
-10^{*}\end{array}$ & $\begin{array}{c}2,13 \pm 1,36 \\
-0,43 \pm 1,12^{*} \\
-9^{*}\end{array}$ & $\begin{array}{c}2,29 \pm 1,43 \\
-0,56 \pm 1,18^{*} \\
-12,5^{*}\end{array}$ \\
\hline
\end{tabular}


cholesterolu $<4 \mathrm{mmol} / \mathrm{l}$ pouze $21,6 \%$ nemocných. Rozdíly $\mathrm{v}$ procentech nemocných, kteří dosáhli cílové hodnoty celkového cholesterolu v podskupině 3 , byly významně nižší než v podskupinách 1 a 2 (p < 0,0001). Mezi podskupinami 1 a 2 statisticky významný rozdíl nebyl nalezen (obrázek 5).

$\mathrm{V}$ celém analyzovaném souboru bez ohledu na kardiovaskulární riziko bylo léčbou statinem dosaženo plazmatické koncentrace celkového cholesterolu $<5$ mmol/l u 69,4\% nemocných. Tuto nejvolnější cílovou hodnotu dosáhlo nejvíce nemocných v podskupině $2(75,1 \%)$, v podskupině 3 to bylo $66,0 \%$ a v podskupině $155,1 \%$. Mezi podskupinami byl zjištěn statisticky významný rozdíl ( $\mathrm{p}<0,0001)$. Přísnější cílovou hodnotu celkového cholesterolu $<4,5 \mathrm{mmol} / 1$ dosáhlo $45,1 \%$ všech nemocných, nejvíce v podskupině $2(50,7 \%)$, o něco méně v podskupině $3(41,8 \%)$ a nejméně v podskupině $1(31,2 \%)$. I v tomto prŕpadě byl mezi podskupinami zjištěn statisticky významný rozdíl ( $\mathrm{p}<0,001)$ (obrázek 6).

V celém analyzovaném souboru dosáhlo cílové hodnoty HDL cholesterolu $>1 \mathrm{mmol} / \mathrm{l}$ pro muže a $>1,2 \mathrm{mmol} / 1$ pro ženy 74,8 \% nemocných. Nejčastěji bylo cílových hodnot dosaženo v podskupině $1(79,1 \% ; \mathrm{p}<0,05$ proti podskupině 2). Mezi podskupinami 2 a 3 nebyl rozdíl $(73,3 \%$ a 75,0 \%, n.s.). Cílové hodnoty triglyceridů $<1,7 \mathrm{mmol} / 1$ dosáhlo v celém souboru 58,3 \% nemocných a nebyl zjištěn žádný rozdíl mezi jednotlivými podskupinami (obrázek 5).

\section{Použité statiny a jejich denní dávky}

Nejčastěji používaným statinem byl bez ohledu na kardiovaskulární riziko a vstupní plazmatickou koncentraci celkového i LDL cholesterolu atorvastatin. Užívalo ho 1735 (54\%) nemocných, v jednotlivých podskupinách podle kardiovaskulárního rizika byla procenta následující: $55 \%$, $55 \%$ a $52 \%$. Simvastatin užívalo celkem 656 (21\%) ne-

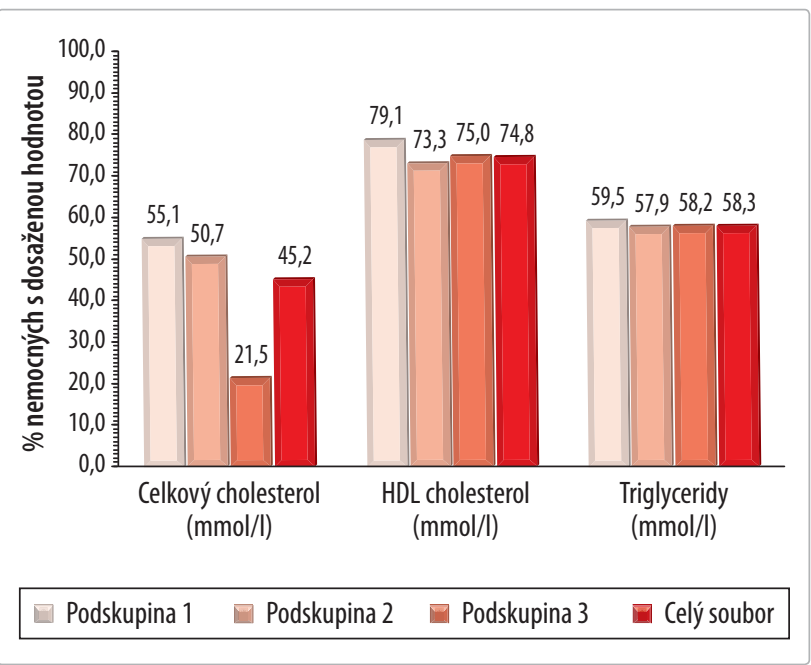

Obrázek 5 Sekundární sledované ukazatele v průzkumu STEP: podíl nemocných $(\mathrm{v} \%) \mathrm{v}$ celém souboru a v jednotlivých podskupinách podle kardiovaskulárního rizika, kteří dosáhli při minimálně roční léčbě statinem cílové hodnoty celkového cholesterolu, HDL cholesterolu a triglyceridů (cílové hodnoty celkového cholesterolu: $v$ podskupině $1<5,0 \mathrm{mmol} / \mathrm{l}$; $\mathrm{v}$ podskupině $2<4,5 \mathrm{mmol} / \mathrm{l} ; \mathrm{v}$ podskupině $3<4,0 \mathrm{mmol} / \mathrm{l}$ )

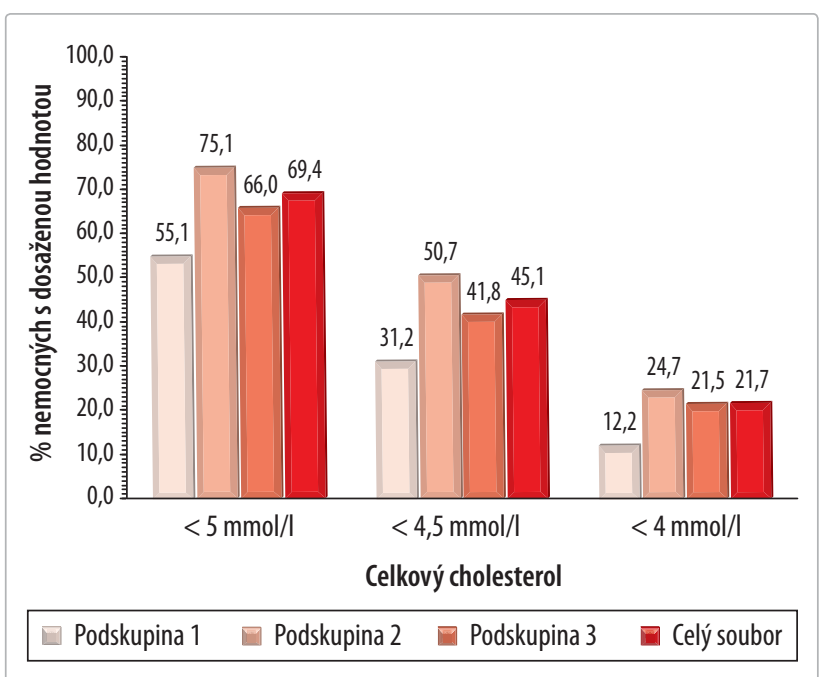

Obrázek 6 Podíl nemocných ( $v$ \%) s dosaženými cílovými hodnotami celkového cholesterolu $<5 \mathrm{mmol} / \mathrm{l} ;<4,5 \mathrm{mmol} / \mathrm{l}$ $\mathrm{a}<4 \mathrm{mmol} / \mathrm{l} v$ celém souboru a $\mathrm{v}$ jednotlivých podskupinách

mocných, v jednotlivých podskupinách to bylo $24 \%, 21 \%$ a $17 \%$. Rosuvastatin užívalo celkem 607 (19\%) nemocných, v jednotlivých podskupinách byl patrný stoupající podíl nemocných užívajících rosuvastatin (13\%, $19 \%$ a $26 \%)$ podle zvyšujícího se rizika. Podíl ostatních statinů byl zcela zanedbatelný - fluvastatin užívalo $5 \%$ nemocných, lovastatin méně něž $1 \%$ nemocných a pravastatin méně než $0,5 \%$ nemocných (tabulka 3). Celkem 673 nemocných (21\%) užívalo kombinovanou hypolipidemickou léčbu (současně se statinem alespoň jeden $\mathrm{z}$ následujících prrípravků: fenofibrát, ezetimib, $\omega-3$ mastné kyseliny). Nejčastěji to byl fenofibrát ( $\mathrm{n}=343 ; 10,8 \%)$ nebo ezetimib $(\mathrm{n}=321 ; 10,1 \%)$, méně často pak $\omega-3$ mastné kyseliny $(n=64 ; 2,0 \%)$.

V tabulce 4 jsou uvedeny denní dávky tří nejpoužívanějších statinů - atorvastatinu, simvastatinu a rosuvastatinu v celém analyzovaném souboru. Jak z této tabulky vyplývá, je zdaleka nejpředpisovanější dávkou všech tří statinů denní dávka $20 \mathrm{mg}$, a to bez ohledu na hypolipidemickou účinnost konkrétního statinu - dávku 20 mg simvastatinu užívalo $55 \%$ všech nemocných, stejně tak užívalo $55 \%$ nemocných $20 \mathrm{mg}$ atorvastatinu a $20 \mathrm{mg}$ rosuvastatinu užívalo dokonce 63 \% všech nemocných. Vztah mezi rizikovou kategorií nemocného, volbou konkrétního statinu a jeho denní dávkou je velmi volný. Podrobná analýza těchto vztahů však bude předmětem jiného sdělení.

\begin{tabular}{|c|c|c|c|c|}
\hline $\begin{array}{l}\text { Účinná } \\
\text { látka }\end{array}$ & $\begin{array}{l}\text { Celý soubor } \\
n=3190\end{array}$ & $\begin{array}{l}\text { Podskupina } 1 \\
\mathrm{n}=597\end{array}$ & $\begin{array}{l}\text { Podskupina } 2 \\
n=1901\end{array}$ & $\begin{array}{l}\text { Podskupina } 3 \\
n=692\end{array}$ \\
\hline atorvastatin & 1735 (54 \%) & $55 \%$ & $55 \%$ & $52 \%$ \\
\hline simvastatin & 656 (21 \%) & $24 \%$ & $21 \%$ & $17 \%$ \\
\hline rosuvastatin & 607 (19\%) & $13 \%$ & $19 \%$ & $26 \%$ \\
\hline fluvastatin & 159 (5 \%) & $6 \%$ & $4,9 \%$ & $4,5 \%$ \\
\hline lovastatin & $20(0,6 \%)$ & $1,2 \%$ & $0,7 \%$ & $0,0 \%$ \\
\hline
\end{tabular}


Etiologie aterosklerózy a jejích nejčastějších klinických manifestací je multifaktoriální, stejně tak multifaktoriální proto musí být i její prevence. Intenzita, resp. agresivita preventivních intervencí by měla být tím větší, čím má intervenovaná osoba vyšší kardiovaskulární riziko. Absolutní kardiovaskulární riziko se stanovuje s pomocí různých skórovacích systémů a z nich odvozených algoritmů, které opět musejí být multifaktoriální. Vycházejí proto z přítomnosti a výše hlavních rizikových faktorů aterosklerózy, obvykle pohlaví, věku, př́tomnosti kuřáckého zlozvyku, diabetes mellitus, hypertenze a dyslipidemie. ${ }^{3,4} \mathrm{~V}$ evropských zemích se ke stanovení absolutního kardiovaskulárního rizika nejčastěji používá skórovací systém SCORE, v Severní Americe nejčastěji framinghamský skórovací systém.

Z ovlivnitelných hlavních rizikových faktorů má největší význam přerušení kuřáckého návyku, které samo o sobě dokáže snížit riziko kardiovaskulárního onemocnění nebo úmrtí z kardiovaskulárních prŕíčin přibližně o polovinu. Bohužel, ani přes dlouhodobě vedenou protikuřáckou kampaň, řadu legislativních opatření a mnohonásobné zdražení tabákových výrobků, se u nás nedaří počet kuřáků významně snižovat. Kouření se spíše jen přesunuje do jiných kategorií osob. Sice mírně ubylo mužů-kuřáků, ale přibylo kouřících žen, po přechodném poklesu absolutního počtu kuřáků jsme svědky nárůstu tohoto zlozvyku v mladších věkových kategoriích. ${ }^{9,10}$

Také boj s diabetes mellitus spíše prohráváme. Vzhledem $\mathrm{k}$ tomu, že diabetes mellitus patři mezi choroby, které podléhají povinné dispenzarizaci, máme o jeho výskytu v naší populaci poměrně přesné údaje. $\mathrm{S}$ moderním nezdravým způsobem života spojeným s chronickým přejídáním se a čím dál větším nedostatkem fyzické aktivity diabetiků v naší populaci nejenom neubývá, ale ke stávajícím přibližně 750000 jich každoročně kolem dalších 50000 přibývá. ${ }^{2,11,12}$ Z hlavních rizikových faktorů tak zůstávají pouze dva, v jejichž intervenci jsme relativně úspěšní. Jsou to hypertenze a dyslipidemie. Zatímco o prevalenci, diagnostice a léčbě hypertenze u nás máme celkem spolehlivé informace $\mathrm{z}$ pravidelně se opakujících průzkumů na reprezentativním vzorku populace, ${ }^{13}$ o prevalenci, diagnostice a léčbě dyslipidemií a její úspěšnosti je u nás informací velmi málo. Navíc ty, které existují, pocházejí vesměs z ordinací praktických lékařů pro dospělé, jako např. výsledky projektu ATRACTIVE $^{14}$ nebo projektu FIAKR. ${ }^{15}$

\begin{tabular}{|c|c|c|c|c|c|c|}
\hline Účinná látka & ODTD & $<10 \mathrm{mg}$ & $10 \mathrm{mg}$ & $20 \mathrm{mg}$ & $40 \mathrm{mg}$ & $80 \mathrm{mg}$ \\
\hline $\begin{array}{l}\text { atorvastatin } \\
\mathrm{n}=1735\end{array}$ & $10 \mathrm{mg}$ & $\begin{array}{l}16 \\
(0,9 \%)\end{array}$ & $\begin{array}{l}263 \\
(15,2 \%)\end{array}$ & $\begin{array}{l}949 \\
(54,7 \%)\end{array}$ & $\begin{array}{l}442 \\
(25,5 \%)\end{array}$ & $\begin{array}{l}60 \\
(3,5 \%)\end{array}$ \\
\hline $\begin{array}{l}\text { simvastatin } \\
\mathrm{n}=656\end{array}$ & $20 \mathrm{mg}$ & $\begin{array}{l}9 \\
(1,4 \%)\end{array}$ & $\begin{array}{l}78 \\
(11,9 \%)\end{array}$ & $\begin{array}{l}360 \\
(55,0 \%)\end{array}$ & $\begin{array}{l}202 \\
(30,8 \%)\end{array}$ & $\begin{array}{l}6 \\
(0,9 \%)\end{array}$ \\
\hline $\begin{array}{l}\text { rosuvastatin } \\
n=607\end{array}$ & $5 \mathrm{mg}$ & $\begin{array}{l}12 \\
(2,0 \%)\end{array}$ & $\begin{array}{l}150 \\
(24,7 \%)\end{array}$ & $\begin{array}{l}383 \\
(63,1 \%)\end{array}$ & $\begin{array}{l}61 \\
(10,1 \%)\end{array}$ & $\begin{array}{l}1 \\
(0,2 \%)\end{array}$ \\
\hline
\end{tabular}

ODTD - obvyklá denní terapeutická dávka podle SÚKL
Projekt ATRACTIV je u nás zřejmě největší průzkum výskytu rizikových faktorů se snahou o jejich maximální ovlivnění nefarmakologickou i farmakologickou intervencí. Bylo do něho zařazeno 4427 osob s vysokým kardiovaskulárním rizikem, které byly v letech 2006-2007 sledovány většinou praktickými lékaři, ale také ambulantními specialisty. Kardiovaskulární riziko zařazených nemocných bylo vysoké, v průměru takřka $10 \%$ podle SCORE, prakticky všichni měli hypertenzi i dyslipidemii, polovina měla diabetes mellitus. Po léčebné intervenci trvající jeden rok došlo k významnému poklesu průměrných hodnot krevního tlaku i k významnému zlepšení prakticky všech lipidových parametrů. Došlo $\mathrm{k}$ poklesu průměrných plazmatických koncentrací celkového cholesterolu o 23 \%, LDL cholesterolu o $28 \%$, triglyceridů o $22 \%$ a vzestupu HDL cholesterolu o 4,5\%. K léčbě dyslipidemií byl však používán jako jediný statin atorvastatin, jeho průměrná denní dávka byla $16 \mathrm{mg} \cdot{ }^{14}$

Do projektu FIAKR bylo zařazeno 1068 mužů a žen ve věku 45-64 let z okresu Mladá Boleslav, kteří byli vybráni k dlouhodobému sledování a intervenci všech intervenovatelných rizikových faktorů u svých praktických lékařů $\mathrm{z}$ centrálního registru pojištěnců metodou náhodného výběru rodných čísel. Dyslipidemii z nich mělo $36 \%$, z nich v době zařazení do projektu takřka polovina (49,5\%) užívala nějaké hypolipidemikum. V naprosté většině to byly statiny (84,7 \%), fibráty užívalo jen 13,8 \%. Dlouhodobé sledování těchto nemocných stále probíhá. ${ }^{15}$

Data $\mathrm{z}$ výše uvedených průzkumů jsou z několika důvodů zkreslena. Kvůli regulačním opatřením (preskripční a indikační omezení) nemohou praktičtí lékaři předepisovat vysokodávkované statiny, do loňského roku, než na trh přišla generika, také nemohli předepisovat rosuvastatin. Rovněž do roku 2010 nemohli předepisovat kombinační hypolipidemickou léčbu. Před několika lety nemohli praktičtí lékaři předepisovat žádné statiny v primární prevenci. Přestože toto preskripční omezení bylo již před několika lety zrušeno a nahrazeno indikačním omezením (podmínkou preskripce statinu v primární prevenci je absolutní kardiovaskulární riziko dle SCORE $\geq 5 \%$ ), někteří praktičtí lékaři stále odmítají nemocným v primární prevenci statiny předepisovat a odkazují je na specialisty, či setrvávají na léčbě fibráty. Selekce nemocných s dyslipidemií, o které se praktičtí lékaři starají, je také dána tím, že nemocní s vysokým a mimořádně vysokým kardiovaskulárním rizikem, často polymorbidní, jsou dispenzarizováni u specialistů, např. kardiologů a diabetologů. Platí to ale jistě i opačně. Nemocní s nižším kardiovaskulárním rizikem, zejména osoby v primární prevenci, jsou pravděpodobně častěji sledováni svými praktickými lékaři než specialisty.

V prezentovaném projektu STEP byla sledována u velkého souboru ambulantních nemocných pouze léčba dyslipidemie a její účinnost. Nemocní byli sledováni ambulantními specialisty, takže výsledky nebyly nijak ovlivněny nemedicínskými faktory, jako jsou výše diskutovaná regulační opatření. K léčbě dyslipidemie nebyl předepsán žádný konkrétní statin, sledování bylo retrospektivní, léčba statinem byla zahájena minimálně rok před zařazením do průzkumu. Tím bylo 
zajištěno, že přestože byl průzkum sponzorován výzkumným grantem farmaceutické společnosti, nebyl výběr konkrétního statinu vůbec ovlivněn firemními zájmy. Průzkum tak relativně věrně odráží skutečný stav hypolipidemické léčby statiny u nás, včetně toho jaké statiny, v jakých dávkách a s jakým léčebným účinkem jsou u nás používány a zda a jak ovlivňuje kardiovaskulární riziko nemocného, event. i výchozí plazmatická koncentrace LDL cholesterolu výběr konkrétního statinu a jeho denní dávku.

Podobně jako u antihypertenzní léčby se účinnost hypolipidemické léčby hodnotí podle toho, zda je léčbou dosaženo cílových hodnot lipidových parametrů, v prrípadě léčby statiny především LDL cholesterolu. Podle stávajících doporučených postupů se však cílové hodnoty mění podle kardiovaskulárního rizika nemocného. Čím je kardiovaskulární riziko vyšší, tím jsou cílové hodnoty přísnější, $\mathrm{v}$ př́padě LDL cholesterolu nižší. ${ }^{3,4,7}$ Proto se účinnost léčby statiny nejvěrněji a nejkomplexněji hodnotí procentem nemocných, kteři při léčbě dosáhnou cílové hodnoty LDL cholesterolu v závislosti na výchozím kardiovaskulárním riziku. Takovéto hodnocení léčebné účinnosti hypolipidemické léčby je klinicky daleko více relevantní než absolutní či relativní pokles jednotlivých lipidových parametrů. Proto jsme v průzkumu STEP zvolili jako primární sledovaný ukazatel podíl nemocných, kteří dosáhnou při léčbě statinem cílové hodnoty LDL cholesterolu odpovídající podle současných guidelines jejich kardiovaskulárnímu riziku.

Výsledky průzkumu STEP jsou podle našeho názoru př́ijemným překvapením. Cílové hodnoty LDL cholesterolu odpovídající kardiovaskulárnímu riziku nemocného bylo léčbou statiny dosaženo u 46,2 \% nemocných. Přitom šlo o léčbu statiny $\mathrm{v}$ reálných podmínkách každodenní praxe v ČR, neovlivněnou protokolem, nuceným výběrem statinu, titrací dávky či předepsanými kontrolami nemocného, které vytvářejí v klinických studiích často umělé „skleníkové“ prostředí, obvykle na hony vzdálené skutečné klinické praxi. Léčebná úspěšnost hypolipidemické léčby statiny celkem přirozeně klesá se zpřísňujícími se cílovými hodnotami. Zatímco u nemocných v primární prevenci, s nižším kardiovaskulárním rizikem je 64,3 \%,v sekundární prevenci klesá na 50,2 \% a u nemocných s mimořádně vysokým kardiovaskulárním rizikem až na 19,5\%. Ale i u té nejrizikovější skupiny nemocných je léčebná úspěšnost hypolipidemické léčby statiny srovnatelná s léčebnou úspěšností antihypertenzní léčby, která u nás nedosahuje ani $20 \%{ }^{13}$ A to jde $\mathrm{v}$ prrípadě léčby statiny většinou o monoterapii, zatímco u léčby hypertenze většinou o kombinační léčbu.

Asi nepřekvapí, že nejužívanějším statinem je u nás atorvastatin. Užívá jej více než polovina všech nemocných, kteří jsou statiny léčeni. Na druhém místě je s $21 \%$ nemocných stále ještě simvastatin, ale rychle se na něho dotahuje s $19 \%$ rosuvastatin, který je u nás k dispozici poměrně krátce. Zatímco podíl nemocných, kteří užívají atorvastatin, je ve všech rizikových kategoriích přibližně stejný (55\%, $55 \%$ a $52 \%$ ), podíl nemocných na simvastatinu mírně klesá se stoupajícím rizikem nemocných $(24 \%, 21 \%$ a $17 \%)$, u rosuvastatinu je tomu naopak (13\%, $19 \%$ a $26 \%)$. Celkem překvapivě je nej- používanější denní dávkou všech statinů denní dávka 20 mg. Platí to pro simvastatin (55\% nemocných), atorvastatin (55\% nemocných) i rosuvastatin (63\% nemocných). Přitom ze srovnání jednotlivých statinů vychází hypolipidemická účinnost rosuvastatinu $\mathrm{k}$ atorvastatinu a $\mathrm{k}$ simvastatinu přibližně $\mathrm{v}$ poměru $1: 2: 4$, to znamená $20 \mathrm{mg}$ rosuvastatinu $=40 \mathrm{mg}$ atorvastatinu $=80 \mathrm{mg}$ simvastatinu. ${ }^{16,17}$ Rosuvastatin v denní dávce 20 mg má přibližně čtyřnásobný hypolipidemický účinek než $20 \mathrm{mg}$ simvastatinu. Teoreticky by měla stoupat hypolipidemická účinnost použitého statinu a jeho denní dávka se stoupajícím kardiovaskulárním rizikem a stoupající výchozí koncentrací LDL cholesterolu. Ve skutečnosti je však vztah mezi použitým statinem a jeho denní dávkou velmi volný. Detailní analýza těchto vztahů bud předmětem dalšího sdělení.

\section{Literatura}

1. Zemřelí 2009. Praha: Ústav zdravotnických informací a statistiky ČR, 2010; www.uzis.cz.

2. Zdravotnictví České republiky 2008 ve statistických údajích. Praha: Ústav zdravotnických informací a statistiky, 2009; www.uzis.cz.

3. Cífková R, Býma S, Češka R, et al. Prevence kardiovaskulárních onemocnění $v$ dospělém věku. Společná doporučení českých odborných společností. Cor Vasa 2005;47(Suppl 9):3-14.

4. Býma $\mathrm{S}$, Hradec J. Prevence kardiovaskulárních onemocnění. Novelizace 2009. Doporučený diagnostický a léčebný postup pro všeobecné praktické lékaře. Centrum Doporučených postupů pro praktické lékaře. Praha: Společnost všeobecného lékařství ČLS JEP, 2009, 12 s.

5. Baigent C, Keech A, Kearney PM, et al. Efficacy and safety of cholesterol-lowering treatment: prospective meta-analysis of data from 90,056 participants in 14 randomised trials of statins. Lancet 2005;366:1267-1278.

6. Ballantyne $\mathrm{CM}$. Low-density lipoproteins and risk for coronary artery disease. Am J Cardiol 1998;82:3Q-12Q.

7. Vaverková H, Soška V, Rosolová H, et al. Doporučení pro diagnostiku a léčbu dyslipidemií v dospělosti. Cor Vasa 2007;49:K73-K86.

8. Hahn GJ, Meeker WQ. Statistical intervals: A guide for practitioners. New York: John Wiley \& Sons Inc., 1991.

9. Králíková $E$, Býma $S$, Cífková $R$, et al. Doporučení pro léčbu závislosti na tabáku. Čas Lék Čes 2005;144:327-333.

10. Čupka J, Nešpor K, Králíková E, et al. Léčba závislosti na tabáku v ordinaci praktického lékaře. Doporučený diagnostický a léčebný postup pro všeobecné praktické lékaře. Praha: CDL-PL, 2005.

11. Výbor ČDS ČLS JEP. Doporučený postup péče o diabetes mellitus 2. typu. Aktualizace 2009. http://www.diab.cz/dokumenty/dm2_2009.pdf.

12. Karen I, Kvapil M, Býma S, Herber O. Diabetes mellitus. Doporučený diagnostický a léčebný postup pro všeobecné praktické lékaře. Praha: CDL-PL, 2005.

13. Cífková R, Škodová Z, Lánská V, et al. Trends in blood pressure levels, prevalence, awarness, treatment, and control of hypertension in the Czech population from 1985 to 2000/01. J Hypertens 2004;22:1479-1485.

14. Vrablík M, Freiberger T, Lánská V, Češka R. Projekt Atractiv: zlepšení kardiovaskulární prevence v podmínkách primární péče v České republice. Vnitř Lék 2008;54:1131-1139.

15. Cífková R, Hradec J, Švihovec J, Býma S. Projekt FIAKR. Plán projektu a vstupní data z okresu Mladá Boleslav. Kap Kardiol 2009;1:107-110.

16. Jones PH, Kafonek S, Laurora I, Hunninghake D. Comparative dose efficacy study of atorvastatin versus simvastatin, pravastatin, lovastatin, and fluvastatin in patiens with hypercholesterolemia (the CURVES study). Am J Cardiol 1988;81:582-587.

17. Jones PH, Davidson MH, Stein EA, et al. Comparison of the efficacy and safety of rosuvastatin versus atorvastatin, simvastatin, and pravastatin across doses (STELLAR Trial). Am J Cardiol 2003;93:152-160.

Došlo do redakce 10. 8. 2011

Prijato 30. 9. 2011 